\title{
EFEKTIFITAS KONTRAK PERILAKU (BEHAVIOR CONTRACT) UNTUK MENINGKATKAN KONSENTRASI BELAJAR SISWA SMAN 1 TAPIN TENGAH
}

\author{
Emma Werdayani \\ SMA Negeri 1 Tapin Tengah
}

\begin{abstract}
ABSTRAK
Penelitian ini Penelitian ini bertujuan untuk mengetahui efektifitas pemberian kontrak prilaku untuk meningkatkan konsentrasi belajar siswa SMAN 1 TAPIN TENGAH, Subjek penelitian ini adalah siswa kelas XI MIA SMAN 1 TAPIN TENGAH yang berjumlah 20orang. Dalam penelitian ini, metode yang diskriptif kualitatif dengan pengumpulan data melaluia observasi dan wawancara kepada peserta didik ada 3 siklus dalam penelitian ini. Pada siklus pertama tidak menggunakan kontrak prilaku ada $40 \%$ siswa yang konsentrasi, Siklus kedua menggunakan kontrak prilaku ada $55 \%$ siswa dan pada siklus ke tida $75 \%$ siswa lebih konsentrasi dalam belajar. Dengan demikian, dapat disimpulkan bahwa kontrak prilaku efektif digunakan untuk dapat meningkatkan konsentrasi belajar.
\end{abstract}

Kata Kunci: kontrak perilaku, konsentrasi belajar

\section{PENDAHULUAN}

Dalam kegaitan layanan klasikal sering ditemui banyak nya siswa yang tidak memperhatikan dan menyimak dengan baik materi yang diberikan oleh guru, hal ini mengakibatkan proses pemberian layanan Bimbingan dan konseling kurang efektif. Perhatian siswa sangat diperlukan untuk ,memaksimalkan proses pemberian layanan agar dapat berjalan dengan baik, agar ada timbal balik Antara guru dan siswa ketika proses pembelajaran berlangsung. Konsentrasi Belajar adalah suatu pemusatan perhatian atau pikiran serta dapat memahami setiap materi pmebelajaran / pembahasan dengan memuat indikator memusatkan pikiran dan perhatian serta pemahaman terhadap sebuah materi tersebut. (Diana Aprilia K. S., 2014). Konsentrasi merupakan bagian dari perhatian yang mana hasl tersebut dapat mempengaruhi usaha seseorang untuk memusatkan perhatian terhadap suatu informasi yang ia butuhkan ataupun mengabaikan informasi yang ia anggap tidak diperlukan (Purwanto, Mei 2010) prilaku yang menunjukkan kurangnya konsentrasi siswa muncul karena adanya beberapa faktor yaitu faktor internal dan juga faktor eksternal, faktor eksternal dapat berupa stimulus stimulus yang berasal dari luar diri siswa, terdapat prilaku yang disebut Perilaku tidak baik (maladaptif) yaitu perilaku yang tidak sesuai atau bertentangan dengan aturan maupun normanorma yang ada (Meiyani., Juni 2018). Prilaku yang tidak baik seperti malas, tidak memperhatikan pelajaran, mengantuk dan berbicara saat guru menjelaskan hal ini tidak hanya menimbulkan kerugian

bagi diri peserta didik, perilaku ini juga merugikan bagi lingkungannya. Kerugian bagi

peserta didik ialah: peserta didik tersebut selalu mendapatkan teguran dari gurunya saat

proses belajar mengajar berlangsung, sehingga bisa menurunkan motivasi belajarnya. Sedangkan motivasi belajar itu sendiri sangat diperlukan untuk siswa agar aktifitas belajarnya dapat berjalan dengan baik dan dapat meraih prestasi (Moncot, 2019) 
Jurnal Inovasi BK,Volume 1, Nomor 2 Desember 2019

Sebagai Guru BK yang merupakan seorang pendidik, memiliki kontribusi penting terhadap keberhasilan belajar siswa, maka sudah semestinya dapat memberikan pelayanan konseling dengan mengupayakan teknik yang efektif dan efisein untuk membantu siswa mencapai keberhasilan akademiknya, Salah satu upaya yang dapat dilakukan adalah dengan menggunakan pendekatan konseling yang tepat, yang dapat digunakan untuk meningkatkan perilaku,Salah satu nya adalah dengan menggunakan Model Konseling behavioral yang dapat digunakan untuk memicu timbulnya motivasi, sehingga siswa dapat terdorong untuk meningkatkan tingkah lakunya yaitu teknik kontrak perilaku. Teknik ini digunakan untuk mengatur kondisi siswa dalam menampilkan tingkah laku yang diharapkan (Yuyun Nuriyah Muslih, JUBK6(1) 2017)

Dengaan adanya kontrak prilaku (behavior contract), yang mana dengan adanya kontrak prilaku diharapkan siswa yang tidak konsentrasi dapam proses pembelajaran dapat berkonsentrasi dengan baik. Kontrak prilaku merupakan suatu tindakan perjanjian yang dilakukan Antara dua orang atau lebih, untuk mengubah suatu prilaku tertentu dengan memberikan suatu tanggung jawab yang merupakan sebuah konsekuensi ketika hal tersebut tidak berubah (Fauzan, 2009)

Pada penelitian sebelumnya perubahan konsentrasi siswa dengan menggunakan metode behavior contract efeftik digunakan karena terlihat dari perubahan sikap yang signifikan setiap kali Siklus pertemuan dibandingkan pertemuan tanpa adanya kontrak layanan (Diana Aprilia K. S., 2014) pelaksanaan layanan konseling kelompok dengan teknik behavioral contract juga sangat efektif digunakan untuk mengurangi kebiasaan membolos sekolah pada siswa (Arroyan Muttaqin Nalman, Desember 2018 ). Tujuan dari penelitian ini adalah untuk mengetahui efektifitas kontrak prilaku yang biasa dilakukan guru secara lisan pada awal pembelajaran.

\section{METODE}

Guna mengetaui efektifitas kontrak layanan pada awal pembelajaran maka saya menggunakan pendekatan deskriptif kualitatif merupakan sebuah metode penelitian yang memanfaatkan data kualitatif dan dijabarkan secara deskriptif. Jenis penelitian deskriptif kualitatif menampilkan hasil data apa adanya tanpa proses manipulasi atau perlakuan lain.sehingga dapat menggambarkan perubahan tingkah laku yang di alami oleh peserta didik sebelum dan sesudah adanya kontrak layanan (behavior contract) tersebut. Terdapat 3 siklus yang dilakukan dalam penelitian ini. subjek dari penelitian ini siswa kelas XI MIA SMAN 1 TAPIN TENGAH, Teknik pengumpulan data dengan melakukan observasi dan wawancara kepada peserta didik, dokumentasi, sedangkan instrument yang digunakan adalah pedoman observasi, pedoman wawancara, analisis data dan lembar dokumentasi.

\section{HASIL DAN PEMBAHASAN}

Penelitian ini difokuskan kepada efektifitas kontrak prilaku yang dilakukan pada awal pembelajaran/ layanan, terhadap konsentrasi siswa saat mengikuti pembelajaran tersebut, (Prayitno, 2004) Pemberian layanan dapat dilaksanakan dalam bentuk klasikal, kelompok dengan metode ceramah, diskusi dan dapat didukung dengan peragaan, pemberian contoh. Salah satu teknik meningkatkan konsentrasi siswa saat pembelajaran berlangsung yaitu dengan teknik kontrak perilaku, yaitu membantu klien untuk membentuk perilaku tertentu yang diinginkan dan memperoleh ganjaran tertentu sesuai dengan kontrak yang disepakati. Belajar merupakan tanggung jawab peserta didik yang mana dari hal 
tersebut berarti ia harus berkonsentrasi belajar dan mengikuti kegiatan pembelajaran dengan baik, jika peserta didik dapat menyadari tanggung jawawabnya tersebut, maka kontrak prilaku ( Behavior Contrak) akan efektif digunakan. (Mega Aria Monica, 2016).

Pada dasarnya dengan menggunakan konseling behavioral dengan teknik modeling dapat meningkatkan self endurance yang salah satunya berfungsinya dapat menumbuhkan cara pandang positif terhadap orang lain. (Ni Made Inggit Gita Yunidar, 2017)prilaku belajar siswa dapat berubah ketika ia memiliki cara pandang yang berbeda maka dari itu dengan Kontrak prilaku siswa dapat merubah kebiasaan siswa jika hal tersebut dilakukan berulangulang pada setiap kali pembelajaran berlangsung.

Untuk memperoleh data untuk mengetahui efektifitas kontrak prilaku dalam pembelajaran maka dilakukan dengan beberapa siklus hal tersebut dilakukan agar dapat melihat presantasi kenaikan dan perubahan setiap pertemuan yang dilakukan.

Pada pembelajaran Siklus pertama kontrak layanan dilakukan dengan lisan namun tidak ada penekanan, proses pembelajaran berjalan dengan rencana, namun masih terlihat pasif lebih banyak guru berbicara dari 20 orang peserta didik yang berhadir, dari hasil observasi hanya ada 6 orang siswa yang memperhatikan dengan seksama terhadap penjelasan yang diberikan oleh guru, 4 orang siswa putra dalam keadaan setengah tertidur, 5 Orang terlihat sedang mengobrol dengan teman sebangkunya yang posisinya persis berada dipojok paling belakang, sedangkan 4 orang lainnya terlihat sedang mengerjakan tugas lain atau sibuk ddengan pekerjaannya sendiri, dan 1 orang sedang melamun. Dari pengamatan tersebut dapat kita lihat bahwa hanya $30 \%$ siswa yang memperhatikan proses pembelajaran dan masih ada $70 \%$ siswa lainnya yang tidak konsentrasi terhadap pelajaran

Kemudian Pada Siklus Kedua guru memberikan kontrak layanan secara lisan kepada siswa dengan meminta siswa untuk memperhatikan dengan baik pembelajaran pada hari ini, dan melakukannya dalam waktu 1x 45 menit atau satu jam pelajaran. Dari hasil observasi dihasilkan dari 20 orang siswa yang hadir ada 11 orang siswa yang memperhatikan dengan baik pembelajaran hari tersebut serta mmberikan respon ketika guru bertanya, ada 4 orang siswa yang masih mengerjakan tugas lain, dan 2 orang siswa yang mengantuk serta 3 orang siswa yang sibuk dengan dirinya sendiri bahkan terkadang sambil mengobrol dengan temannya, dari observasi tersebut dapat dilihat bahwa ada peningkatan perhatian siswa kepada guru yang meningkat sebanyak 15 persen yakni dari $40 \%$ menjadi $55 \%$ siswa yang memperhatikan penjelasan Guru.

Pada Siklus ke tiga pembelajaran dilakukan kontrak layanan di awal seperti pada siklus kedua, dari 20 orang siswa ada 15 orang siswa yang mmeperhatikan guru 5 orang lainnya masih sibuk dengan dirinya sendiri atau melakukan kegiatan lainnya, dari sini terlihat prsentasi kenaikan perhatian siswa ketika adanya kontrak layanan di awal pembelajan pada siklus ke tiga ada $75 \%$ siswa yang memperhatikan pembelajaran.

Tabel. Presentasi kenaikan Konsentrasi siswa

\begin{tabular}{ccc}
\hline Siklus & $\begin{array}{c}\text { Siswa } \\
\text { konsentrasi }\end{array}$ & $\begin{array}{c}\text { Siswa tidak } \\
\text { Konsentrasi }\end{array}$ \\
\hline I & $30 \%$ & $70 \%$ \\
\hline II & $55 \%$ & $45 \%$ \\
\hline III & $75 \%$ & $25 \%$ \\
\hline
\end{tabular}


Jurnal Inovasi BK,Volume 1, Nomor 2 Desember 2019

Metode komperasi yang digunakan untuk menarik kesimpulan, peneliti menggunakan rumus statistic sederhana

$$
P=\frac{f}{N} \times 100 \%
$$

Keterangan

P : Angka Presentasi

$\mathrm{F} \quad$ : Frekuensi yang sedang dicari

N : Number Of cases (Sudijono, 2006)

Dimana kemudian hasil

penghitungan tersebut di interpretasikan ke

dalam kreteria tingkat efektifitas sebagai berikut ;

Sangat Efetktif $\quad: 80 \%-100 \%$

Efektif $\quad: 60 \%-79 \%$

Cukup Efektif $\quad: 40 \%-59 \%$

Kurang Efektif $\quad:<40 \%$

Kriteria tersebut penulis buat berdasarkan pada pernyataan dari E.

Mulyasa bahwa dari segi hasil, pembelajaran dikatakan berhasil apabila terjadi

perubahan perilaku yang positif pada diri peserta didik seluruhnya ata setidak tidaknya sebagian besar (75\%) (Mulyasa, 2005)

Hasil wawancara kepada siswa menunjukkan bahwa ketika dilakukan kontrak layanan pada awal pembelajaran akan dimulai, siswa secara tidak langsung membuat fokus perhatian berpindah kepada guru untuk memperhatikan petunjuk guru dan mengikuti yang arahan yang diberikan guru, alasan siswa tidak memperhatikan guru atau mengantuk selama proses pembelajaran karena materi yang kurang menarik atau penyampaiannya yang kurang menarik

Penerapan kontrak prilaku (behavior contract), pada awal pembelajaran bisa dapat dikatakan efektif digunakan untuk meningkatkan konsentrasi belajar siswa,yang terlihat dari perhatian siswa yang meningkat, pada siklus pertama presentasi kurang efektif karena penekanan kontrak kurang dan siswa belum terbiasa, pada siklus kedua sudah cukup efektif, dan pada siklus ketiga susdah dapat dikategorikan Efektif karena presentasi siswa yang konsentrasi dengan memfokuskan perhatiannya sebanyak $75 \%$. saat dilakukan kontrak layanan secara lisan guru meminta siswa memberikan respon dan siswa merespon dengan baik, maka secara langsung kontrak itu berjalan sesuai rencana dengan konsekuensi yang sudah disepakati.

\section{KESIMPULAN}

Dari data diatas maka dapat disimpulkan bahwa pelaksanaan kontrak layanan pada awal pembelajaran secara lisan sangat efektif digunakan untuk meningkatkan konsentrasi dan perhatian siswa SMAN 1 Tapin Tengah saat Proses pembelajaran, Hal tersebut dapat dilihat dari meningkatnya presentasi perhatian siswa yang pada siklus pertama $30 \%$ pada siklus kedua 55\% selajutnya pada siklus ke tiga sebanyak $75 \%$ siswa konsentrasi mengikuti pembelajaran. Setiap pertemuan ada kenaikan presentasi yaitu sekitar $15 \%$.

\section{DAFTAR PUSTAKA}

Arroyan Muttaqin Nalman, D. S. (Desember 2018 ). Efektifitas Konseling Kelompok Dengan Teknik Behavioral ContractUntuk Mengurangi Kebiasaan Membolos Siswa Kelas XISMA Negeri 8 Kota Bengkulu. JURNAL PSIKODIDAKTIKA \| VOL:3, $\mathrm{NO}: 2,31$.

Diana Aprilia, K. S. (2014). PENERAPAN KONSELING KOGNITIF DENGAN TEKNIK PEMBUATAN KONTRAK (CONTINGENCY CONTRACTING) UNTUK MENINGKATKAN

KONSENTRASI BELAJAR SISWA KELAS $X$ TKR1 SMK NEGERI 3 SINGARAJA. e-journal Undiksa Jurusan Bimbingan Konseling, 1. 
Fauzan. (2009). Kontrak Perilaku. (online). https://lutfifauzan.wordpress.com/20 09/08/09/kontrak-perilaku/.

Mega Aria Monica, R. A. (2016). Efektivitas Layanan Konseling Behavioral dengan Teknik SelfManagement untuk mengembangkan Tanggung jawab belajar pada peserta didik kelas XI SMA ALAZHAR 3 Bandar Lampung Tahun Ajaran 2015/2016. KONSELI: Jurnal Bimbingan dan Konseling (EJournal), 119-132.

Meiyani., I. S. (Juni 2018). TEKNIK BEHAVIOR CONTRACT UNTUK MENGURANGI PERILAKU HYPERAKTIF PADA PESERTA DIDIK LOW VISION. JASSI_anakku Volume 19 Nomor 1, 1.

Moncot. (2019). Hubungan aktivitas belajar dan motivasi dengan hasil belajaar tahfiz Al-Quran ( Studi pada MTS Darul Quran deli serdang). Jurnal ANSIRU PAI Vol.3 No.I, 18-32.

Mulyasa, E. (2005). Menjadi Guru Profesional Menciptakan Pembelajaran kreatif dan menyenangkan. Bandung: Remaja Rosdakarya Offset.

Ni Made Inggit Gita Yunidar, I. K. (2017). Konseling Behavioral Dengan Teknik Modeling Efektif Untuk Meningkatkan Self Endurance Pada. Jurnal Bimbingan Konseling Indonesia UNDIKSHA.

Prayitno. (2004). Layanan Bimbingan. PADANG: Universitas Negeri Padang.

Purwanto, A. N. (Mei 2010). EFEKTIVITAS BRAIN GYM DALAM MENINGKATKAN KONSENTRASI BELAJAR PADA ANAK. Indigenous, Jurnal Ilmiah Berkala PsikologiVol. 12, No. 1, 8889.
Sudijono, A. (2006). Pengantar Evaluasi Pendidikan. Jakarta : Rajawali Press.

Yuyun Nuriyah Muslih, M. E. (JUBK6(1) 2017). Konseling Behavioral menggunakan Teknik Kontrak Perilaku dengan Students' Logbook untuk Meningkatkan Minat Membaca Siswa. Jurnal Bimbingan Konseling Prodi Bimbingan Konseling, Pascasarjana, Universitas Negeri Semarang, Indonesia, 34-43. 